\title{
Perbandingan Efektifitas Ekstrak Etanol Daun Binahong (Anredera Cordifolio (Ten) Steenis) Dengan MEBO (Moist Exposed Burn Ointment) Terhadap Penyembuhan Luka Bakar Derajat II A Pada Tikus Putih Jantan (Rattus Norvegicus). Sisca Dwi Saputri*, Taufan Citra Darmawan** Email :Tp4nThefujin@yahoo.com
}

\begin{abstract}
ABSTRAK
Indonesia memiliki banyak tanaman yang berkhasia tobat. Salah satu tanaman yang berkhasiat dan digunakan masyarakat yaitu tumbuhan daun binahong. Pengalaman peneliti menunjukan tumbuhan daun binahong dapat digunakan sebagai obat luka. Kandungan daun binahong seperti minyak astiri, asam oleanolik, alkaloid dan zat lainnya diduga dapat menyembuhkan luka. Penelitian ini bertujuan untuk mengetahui perbandingan efektifitas antara ekstrak etanol daun binahong dengan mebo terhadap penyembuhan luka bakar pada tikus putih jantan.Jenis penelitian ini adalah true experiment dengan rancangan post-test only group design. Teknik sampling yang digunakan dalam penelitian ini yaitu Purposive Sampling. Penelitian ini menggunakan 20 ekor yang dibagi menjadi dua kelompok yaitu 10 ekor perlakuan menggunakan ekstrak etanol daun binahong dan 10 ekor perlakuan menggunakan meboyang dilakukan di Laboratorium Biokimia Fakultas Kedokteran Universitas Hang Tuah Surabaya. Analisis hipotesis penelitian menggunakan uji Independent T - Test.

Hasil dari penelitian ini diperoleh $\mathrm{p}=0,02$ berdasarkan rata-rata waktu penyembuhan luka bakar derajat II A yang dibandingkan dengan tingkat kemaknaan 0,05 maka diperoleh hasil $\rho(0,02)<\alpha(0,05)$. Sehingga dari hasil SPSS didapatkan H1diterima dan H0 ditolak.

Kesimpulan dari penelitian ini adalah ada perbandingan efektifitas ekstrak etanol daun binahong (anrederacordifolia (ten) steenis) dengan mebo (moist exposed burn ointment) terhadap luka bakar derajat IIA pada tikus putih jantan (rattus norvegicus).
\end{abstract}

Kata Kunci : Daun binahong, penyembuhan luka bakar derajat II, lukabakar

\section{ABSTRACT}

Burn injury is not ordinary cuts. Burns directly impact local and systemic in the body that does not occur in most of the other injuries. Burn injury is defective portion of body shock or animal bites. The purpose of this research is to know the difference in the effectiveness of the granting of honey with virgin coconut oil againts the long healing II degree burns white male rats (Rattus Norvegicus) age 23 months.

The type of research is a true experiment with post-test only control group design. The sampling technique used in this study i.e. random sampling. This research used 22 tail is divided into two groups, the 11 tail treatment using honey and 11 tail treatment using a virgin coconut oil that is done in the Laboratory of Biochemistry Faculty of Medicine Hang Tuah University in Surabaya. Analysis of the reaearch hypothesis test using Independent Samples Test.

The results of this research obtained $p=0,000$ of based on average time of healing II degree burns in comparison with the level of significance 0,05 of obtained results $(0,000)<\alpha(0,05)$. So from the results obtained by SPSS H1 accepted and HO is rejected.

The conclusion from this study is there is a difference in the effectiveness of the granting of honey with virgin coconut oil againts the long healing II degree burns. In this case the researchers advise to use topical herbal medicines in therm of healing II degree burns.

Keyword : The Healing II Degree Burns, Honey, Virgin Coconut Oil 


\section{PENDAHULUAN}

Kebudayaan di Tulungagung Jawa Timur banyak yang mengatakan bahwa daun binahong (Anredera cordifolia (Ten) Steenis) sebagai alternatif dalam menyembuhkan luka, seperti pengalaman peneliti yang telah membuktikan jika daun tersebut bisa menjadi alternatif penyembuhan luka, namun teknik penggunaan daun binahong masih dilakukan secara tradisional yaitu dengan ditumbuk. Terdapat banyak varian obat topikal yang berada dikalangan masyarakat sebagai alternatif penyembuhan luka bakar, salah satu obat luka bakar yang dijadikan standar pengobatan di beberapa rumah sakit yaitu MEBO (Moist Exposed Burn Ointment). Luka dapat dialami semua orang tanpa memandang usia, ras maupun jenis kelamin. Luka merupakan suatu keadaan hilangnya atau rusaknya sebagian jaringan tubuh karena perubahan suhu yang tinggi, sengatan listrik, ledakan, maupun terkena bahan kimia. Berdasarkan penelitian tersebut proses penyembuhan luka bakar dapat berlangsung lama, karena dibutuhkan volume jaringan penghubung yang lebih untuk memperbaiki kerusakan dan karena kekurangan lapisan epidermis untuk menahan mikroorganisme yang masuk, maka dapat diketahui bahwa luka bakar rentan untuk terjadi infeksi (Brunner \& Suddart, 2010).

Prevalensi kejadian luka bakar didunia adalah pada tahun 2007-2009 tercatat per 100.000 orang yaitu negara yang mempunyai prevalensi terendah adalah Singapura $(0,05 \%)$ dan prevalensi tertinggi adalah Finlandia (1,98\%) (The World Fire Data Statistic Centre, 2012). Di Asia tercatat sekitar 195.000 jiwa yang meninggal karena luka bakar (WHO 2012). Berdasarkan data di Amerika menunjukkan kurang lebih, sekitar 1 juta orang menderita luka bakar dengan 12.000 diantaranya meninggal dunia di Amerika Serikat (Edelman, 2009). Luka bakar paling sering terjadi di rumah dan yang ditemukan terbanyak adalah luka bakar derajat II (Nurdiana dkk, 2008). Survey yang dilakukan di 3500 rumah sakit di India menunjukkan tingkat kematian akibat luka bakar adalah $25 \%$ hingga $49 \%$ pada dewasa dan $6 \%$ hingga $20 \%$ pada anak-anak. Di Indonesia direfleksikan dengan data di Rumah Sakit Cipto Mangunkusumo Jakarta yang mencatat kejadian luka bakar sebanyak 107 kasus dengan $37,38 \%$ angka kematian terjadi selama menjalani perawatan pada tahun 2012 (Martina \& Wardhana,2013). Rumah Sakit Sanglah selaku rumah sakit rujukan di Bali mencatat 217 kasus yang terjadi pada tahun 2011 dengan angka kematian sebesar 39\%. Sedangkan data di rumah sakit rujukan di Jawa Timur terdapat data di burn unit RSU Dr. Soetomo Surabaya menunjukkan jumlah kasus yang dirawat dari bulan Januari 2014 hingga Desember 2014 sebanyak 157 kasus yang didominasi pasien laki-laki sebanyak 102 orang dan pasien perempuan sebanyak 55 orang, sedangkan 2015 bulan Oktober menurun menjadi 78 kasus yang terdiri dari 44 pasien. Dari jumlah pasien yang dirawat dari bulan Januari hingga Oktober 2015 diperoleh data pasien yang mengalami luka derajat II sebanyak 75 kasus, sedangkan luka bakar derajat III sejumlah 8 kasus. Kematian akibat luka bakar derajat 2 di burn unit RSU Dr. Soetomo pada bulan Januari hingga oktober 2015 sebanyak10 kasus atau sekitar 20\% dan dari bulan Januari hingga oktober 2015 sebanyak 10 kasus atau sekitar 13\%. (Data burn unit RSU Dr. Soetomo Surabaya 2015).

Penggunaan daun binahong (Anredera cordifolia (Ten.) Steenis) pada luka terbukti meningkatkan waktu penyembuhan luka. Adanya senyawa flavonoid, dimana secara farmakologi senyawa flavonoid berfungsi sebagai zat anti inflamasi, anti oksidan, analgesik dan anti bakteri (Manoi, 2009). Salep ekstrak daun binahong (Anredera cordifolia (Ten.) Steenis) telah terbukti memiliki efek antinflamasi, antimikroba dan antioksidan (Astuti et al 2011). Moist Exposed Burn Ointment (MEBO) merupakan obat topikal yang digunakan masyarakat untuk penyembuhan luka bakar. MEBO pertama kali diperkenalkan oleh Professor Roxiang pada tahun 1980 (Hindy, 2009). Menurut penelitian Jewo dkk. (2009), MEBO mampu mengobati $90 \%$ lebih cepat dibanding Silver Sulfadiazin. Penggunaan MEBO ternyata memiliki hambatan berupa harga yang relative tinggi dibandingkan jenis obat luka bakar lainnya. Perawatan luka dari tahun ke tahunnya telah mengalami perkembangan yang sangat pesat. Secara umum, perawatan luka yang berkembang pada saat ini lebih ditekankan pada intervensi yang melihat sisi klien dari berbagai dimensi, yaitu dimensi fisik, psikis, ekonomi dan social. Saat ini sedang dikembangkan terapi luka bakar melalui pemberian topikal dengan ekstrak herbal 
(Gauglitz, 2011). Menurut Kartini (2009); Rio dkk., (2012) dalam jurnal Angga (2011) harga krim silver sulfadiazine $1 \%$ masih cukup mahal, sehingga tidak semua masyarakat Indonesia mampu membelinya. Meskipun terdapat kemajuan yang luar biasa dalam industri obat farmasi, namun masih banyak pengobatan tradisional yang masih digunakan masyarakat Indonesia terutama di daerah pedesaan yang masih kaya dengan keanekaragaman tumbuhannya (Saumantera, 2013). Indonesia adalah negara yang kaya dengan bahan alam terutama tumbuhan yang berpotensi besar untuk dimanfaatkan dan dikembangkan secara maksimal. Perubahan sikap kembali ke alam (back to nature) sekarang ini justru membuat pemanfaatan tanaman obat semakin meningkat. Tumbuhan merupakan sumber bahan alam yang banyak manfaatnya sebagai bahan obat. Dengan adanya kesadaran masyarakat tentang dampak negatif obat-obatan berbahan kimia maka mereka mulai kembali ke pengobatan dengan menggunakan obat tradisional yang berkhasiat sebagai obat untuk mengobati berbagai macam penyakit. Salah satu tanaman yang memiliki banyak khasiat dalam mengobati penyakit ialah daun binahong (Anredera cordifolia (Ten) Steenis) (Paju et al 2013).

Berdasarkan latar belakang diatas dan dari beberapa hasil penelitian daun binahong (Anredera cordifolia (Ten) Steenis) dan salep MEBO (Moist Exposed Burn Ointment) yang dijadikan standar pengobatan di beberapa rumah sakit dapat menyembuhkan luka bakar, peneliti tertarik melakukan penelitian tentang perbandingan tingkat efektifitas kesembuhan luka bakar antara pemberian ekstrak etanol daun binahong (Anredera cordifolia (Ten) Steenis) dengan salep MEBO (Moist Exposed Burn Ointment) yang akan diujikan pada tikus putih jantan (Rattus Norgicus).

\section{METODE}

Penelitian ini adalah penelitian true experiment dengan rancangan post test only group design. Rancangan ini juga merupakan eksperimen sungguhan dan hampir sama dengan rancangan yang telah dibicarakan sebelumnya, hanya bedanya tidak diadakan pretest (Notoadmodjo, 2010). Karena kasus-kasus telah dirandomisasi baik pada kelompok eksperimen perawatan luka bakar derajat II A menggunakan ekstrak etanol daun binahong maupun kelompok eksperimen perawatan luka bakar derajat II A menggunakan salep mebo. Kelompokkelompok tersebut dianggap sama sebelum dilakukan perlakuan. Populasi dalam penelitian ini adalah tikus putih (rattus norvegicus) jantan di Lab. Biokimia Fak. Kedokteran Universitas Hang Tuah Surabaya yang berjumlah 20 ekor. Teknik sampling yang digunakan dalam penelitian ini yaitu Purposive Sampling.

Pengujian hipotesis dengan analisa bervariat menggunakan uji Independent T-Test (untuk mengetahui perbedaan dua variabel independen terhadap variabel dependen) merupakan salah satu jenis uji komparatif non parametris yang dilakukan pada dua variabel, ada 2 variabel menunjukkan data normal maka dilakukan uji Independent T-Test.

\section{HASIL}

Di dalam data umum di uraikan tentang umur, jenis kelamin, berat badan tikus dan jenis tikus.

Tabel 1. Karakteristik hewan percobaan berdasarkan umur tikus

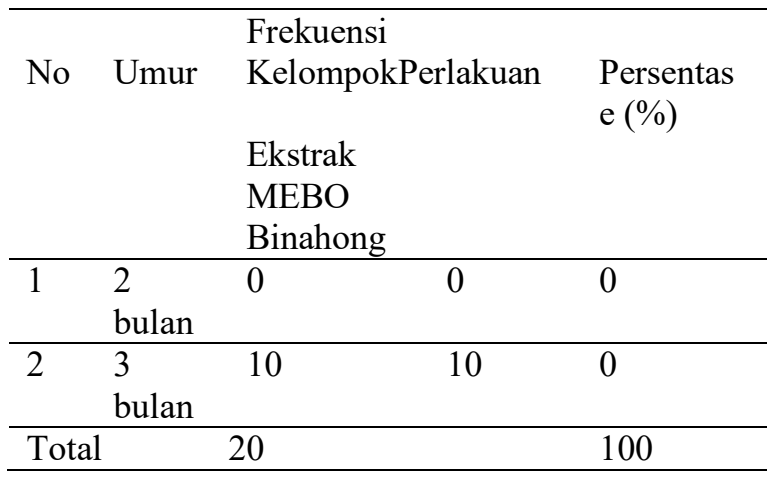

Berdasarkan tabel diatas dapat diketahui bahwa pada hewan coba seluruhnya berumur 3 bulan sebanyak 20 ekor (100\%).

Tabel 2. Karakteristik hewan percobaan berdasarkan jenis kelamin tikus

\begin{tabular}{lllll}
\hline No & $\begin{array}{l}\text { Jenis } \\
\text { Kelamin }\end{array}$ & $\begin{array}{l}\text { Frekuensi } \\
\text { Kelompok Perlakuan } \\
\end{array}$ & $\begin{array}{l}\text { Persentase } \\
(\%)\end{array}$ \\
& & $\begin{array}{l}\text { MEBstrak } \\
\text { Binahong }\end{array}$ & \\
\hline 1 & Jantan & 10 & 10 & 100 \\
\hline 2 & Betina & 0 & 0 & 0 \\
\hline Total & 20 & & 100 \\
\hline
\end{tabular}


Berdasarkan tabel diatas menunjukkan bahwa sebagian besar hewan percobaan berjenis kelamin jantan sebanyak 20 ekor (100\%).

Tabel 3. Karakteristik hewan percobaan berdasarkan berat badan tikus

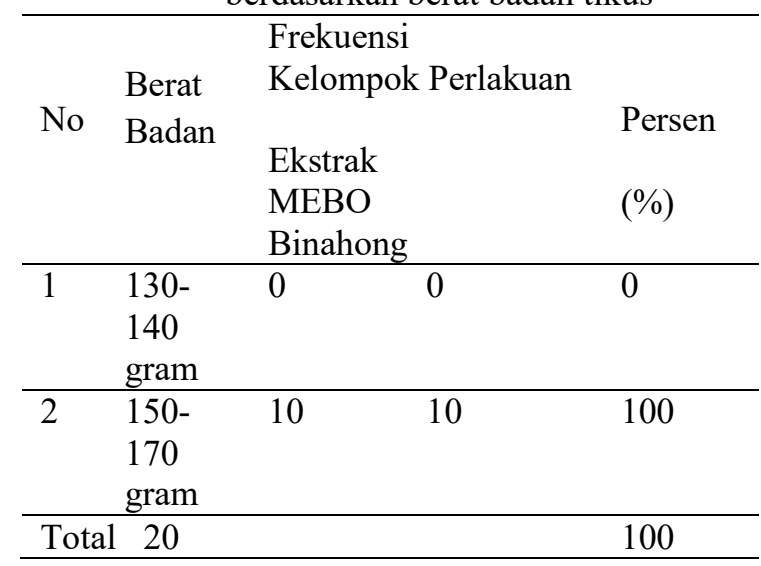

Berdasarkan tabel diatas dapat diketahui bahwa seluruh hewan coba sebanyak 20 ekor $(100 \%)$ mempunyai berat badan 150 170 gram.

Tabel 4. Distribusi frekuensi perbandingan efektifitas pada kelompok perlakuan 1 menggunakan ekstrak etanol daun binahong (Anrederacordifolia (Ten) Steenis)

\begin{tabular}{llll}
\hline No. & $\begin{array}{l}\text { Kriteria } \\
\text { Luka }\end{array}$ & Frekuensi & Persen (\%) \\
\hline 1 & Baik & 8 & 80 \\
\hline 2 & KurangBaik & 2 & 20 \\
\hline 3 & TidakBaik & 0 & 0 \\
\hline & Total & 10 & $100 \%$ \\
\hline
\end{tabular}

Berdasarkan tabel diatas menunjukkan bahwa sebagian besar hewan percobaan pada kelompok perlakuan 1 menggunakan ekstrak daun binahong dalam kriteria proses penyembuhan luka bakar, sebagian besar yang mendapatkan hasil baik 8 ekor (80\%) dan sebagian kecil yang mendapatkan nilai sedang atau kurang baik sebanyak 2 ekor (20\%).
Tabel 5. Rata-rata waktu penyembuhan luka pada kelompok perlakuan 1

\begin{tabular}{|c|c|c|}
\hline No & No. Sampel & $\begin{array}{ll}\text { Waktu } & \text { Rata2 } \\
\text { Penyembuhan } & \end{array}$ \\
\hline 1 & P1 & 10 \\
\hline 2 & P2 & 11 \\
\hline 3 & P3 & 10 \\
\hline 4 & P4 & 10 \\
\hline 5 & P5 & 10 Hari \\
\hline 6 & P6 & 11 \\
\hline 7 & P7 & 11 \\
\hline 8 & P8 & 10 \\
\hline 9 & P9 & 10 \\
\hline 10 & P10 & 10 \\
\hline & Total & 103 \\
\hline $\begin{array}{l}\text { dike } \\
\text { perl } \\
\text { dala } \\
\text { yakr } \\
\text { Tab }\end{array}$ & 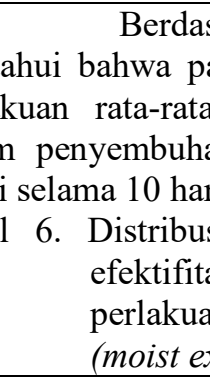 & $\begin{array}{l}\text { arkan tabel diatas dapat } \\
\text { da hewan coba kelompok } \\
\text { waktu yang dibutuhkan } \\
\text { n luka bakar derajat IIA } \\
\text { i frekuensi perbandingan } \\
\text { s pada kelompok } \\
2 \text { menggunakan mebo } \\
\text { posed burn ointment) }\end{array}$ \\
\hline No. & $\begin{array}{l}\text { Kriteria } \\
\text { Luka } \\
\text { Bakar }\end{array}$ & $\begin{array}{ll}\text { Frekuensi } & \begin{array}{l}\text { Presentase } \\
(\%)\end{array}\end{array}$ \\
\hline 1 & Baik & 70 \\
\hline 2 & $\begin{array}{l}\text { KurangBai } \\
\mathrm{k}\end{array}$ & 30 \\
\hline 3 & TidakBaik & 0 \\
\hline & Total & $100 \%$ \\
\hline
\end{tabular}

Berdasarkan tabel diatas dapat diketahui bahwa pada hewan coba pada kelompok perlakuan 2 luka baik 7 ekor $70 \%$ ) dan luka kurang baik 3 ekor (30\%). 
Tabel 7. Rata-rata waktu penyembuhan luka pada kelompok perlakuan 2

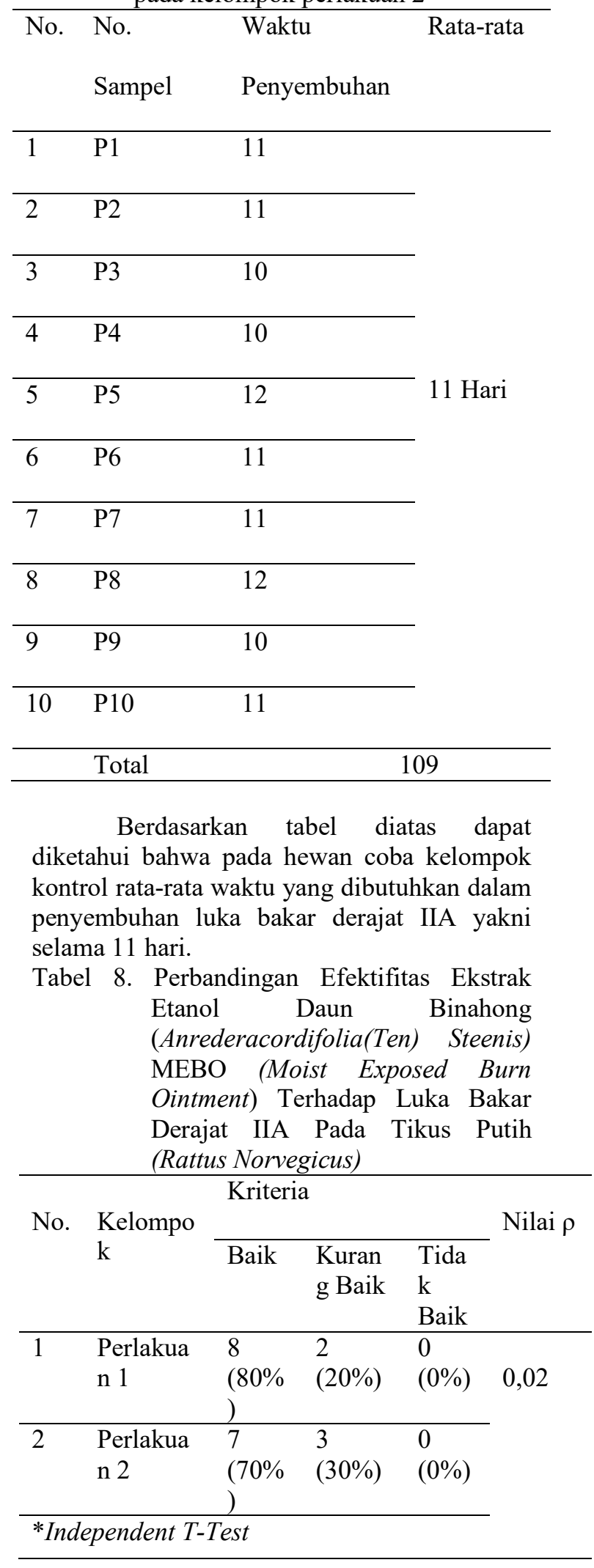

\begin{tabular}{|c|c|c|c|c|}
\hline No & Kelompok & $\mathrm{N}$ & $\begin{array}{l}\text { Mea } \\
n\end{array}$ & $\rho$ \\
\hline 1. & $\begin{array}{l}\text { Kelompok } \\
1\end{array}$ & 10 & $\begin{array}{l}13,7 \\
3\end{array}$ & 0,02 \\
\hline 2. & $\begin{array}{l}\text { Kelompok } \\
2\end{array}$ & 10 & $\begin{array}{l}13,3 \\
4\end{array}$ & \\
\hline
\end{tabular}

Berdasarkan hasil perhitungan statistik Independent T-Test dengan dengan tingkat $\alpha<$ 0,05 didapatkan hasil $\rho(0,02)<\alpha(0,05)$ yang artinya $\mathrm{H} 1$ diterima sehingga dari hasil spss didapatkan ada perbandingan efektifitas ekstrak etanol daun binahong (anredera cordifolia (ten) steenis) dengan mebo (moist exposed burn ointment) terhadap luka bakar derajat IIA pada tikus putih (rattus norvegicus).

\section{PEMBAHASAN}

Perbandingan Efektifitas Ekstrak Etanol Daun Binahong (Anredera cordifolia (Ten) Steenis)Pada Perlakuan Kelompok 1 Terhadap Penyembuhan Luka bakar Derajat II A Pada Tikus Putih Jantan (Rattus Norvegicus)

Berdasarkan hasil penelitian yang dilakukan peneliti menunjukkan bahwa pada perlakuan kelompok 1 menggunakan ekstrak dun binahong dalam kriteria proses penyembuhan luka bakar sebagian besar yang mendapatkan hasil baik sebanyak8 ekor $(80 \%)$ dan sebagian kecil yang mendapatkan nilai sedang atau kurang baik sebanyak 2 ekor (20\%).

Menurut Harborne dan Guenther 1987 menjelaskan bahwa Daun Binahong memiliki kandungan pada proses penyembuhan luka, kandungan tersebut adalah polifenol yang berfungsi sebagai anti inflamasi (60-75\%) dan minyak atsiri berfungsi sebagai antibiotik dimana antibiotik ini menghambat perkembangbiakan sel inflamasi pada luka.

Menurut peneliti, kandungan dalam daun binahong (minyak atsiri sebagai antibiotik dan saponin menyebabkan luka tidak mengalami infeksi sehingga penyembuhan berlangsung cepat dan pengobatan secara teratur membuat kondisi luka akan semakin membaik dan tidak terjadi infeksi.

Berdasarkan hasil penelitian yang dilakukan menunjukan bahwa pada perlakuan kelompok 1 rata-rata waktu dalam proses penyembuhan luka bakar derajat IIA selama 10 hari. 
Suseno (2013) menjelaskan bahwa dalam daun binahong terdapat aktivitas antioksidan, asam askorbat, dan total fenol yang sangat tinggi. Dalam daun binahong terdapat kandungan antibakterial dan sitotoksik, juga mengandung asam oleanolik yang memiliki khasiat sebagai antiinflamasi dan untuk mengurangi rasa nyeri pada luka bakar. Emmanuel B. Thompson 2013, menjelaskan mengapa pada hewan coba tikus putih kelompok perlakuan waktu penyembuhan lebih cepat, hal ini disebabkan karena proses pengobatan dan pengobatan secara teratur selama proses penyembuhan luka.

Menurut peneliti, proses penyembuhan dalam penelitian perlakuan kelompok 1 disebabkan oleh kandungan antibakterial dan sitotoksikyang berperan dalam proses penyembuhan luka bakar derajat IIA, perawatan hewan selama masa coba nutrisi dan lingkungan yang memadahi juga menjadi faktor pendukung cepatnya proses penyembuhan.

Perbandingan Efektifitas Ekstrak Etanol Daun Binahong (Anredera cordifolia (Ten) Steenis) Pada Perlakuan Kelompok 2 Terhadap Penyembuhan Luka bakar Derajat II A Pada Tikus Putih Jantan (Rattus Norvegicus)

Berdasarkan hasil penelitian yang dilakukan menunjukkan bahwa pada perlakuan kelompok 2 menggunakan MEBO dalam proses penyembuhan luka mendapatkan hasil luka baik 7 ekor $(70 \%)$ dan luka kurang baik 3 ekor $(30 \%)$.

Moist Exposed Burn Ointment (MEBO) Berdasarkan The Chinese Technical Center of Burns Wounds \& Surface Ulcers (2000), salep MEBO mengandung minyak wijen (sesame oil) dan lilin lebah (beeswax) serta dikombinasikan dengan berbagai jenis herbal. Kombinasi bahan aktif tersebut akan mempermudah pengelupasan jaringan mati pada luka bakar (liquefaction), memicu proses regenerasi in situ, sekaligus berperan sebagai nutrisi untuk proses penyembuhan luka.

Menurut peneliti, hewan percobaan pada perlakuan kelompok 2 yang mendapatkan hasil luka kurang baik ada 3 ekor dikarenakan faktor imunitas karena setiap ekor tikus berbeda-beda dalam menerima intervensi dari luar serta faktor mekanik (gerak) pada tikus yang aktif akan menyebabkan keadaan luka semakin memburuk sehingga menghambat penyembuhan luka.

Menurut Mylene Mona, 2013 gangguan sistem imun akan mengubah reaksi tubuh terhadap luka, kematian jaringan dan kontaminasi. Bila sistem daya tahan tubuh, baik seluler maupun hormonal terganggu maka pembersihan kontaminasi dan jaringan mati serta pertahanan infeksi tidak berjalan baik. Faktor mekanik (gerak) akan mempengarui pergerakan dini pada daerah yang luka sehingga keadaan luka akan memburuk dan dapat menghambat penyembuhan luka.

Berdasarkan hasil penelitian yang dilakukan peneliti menunjukan bahwa pada perlakuan kelompok 2 rata-rata waktu yang dibutuhkan dalam penyembuhan luka bakar yakni selama 11 hari.

Sesuai dengan teori Emmanuel B. Thompson 2013, menjelaskan mengapa pada hewan coba tikus putih perlakuan kelompok 2 waktu penyembuhan kurang cepat. Hal ini disebabkan faktor imunitas karena setiap ekor tikus berbeda-beda dalam menerima intervensi dari luar serta faktor mekanik (gerak) pada tikus yang aktif akan menyebabkan keadaan luka semakin memburuk sehingga menghambat penyembuhan luka.

Menurut peneliti, waktu yang dibutuhkan dalam penelitian pada perlakuan kelompok 2 tidak ada bedanya dengan perlakuan kelompok 1, dikarenakan pada kelompok perlakuan 2 perawatan dan pengobatan dilakukan secara bersih dan ditutup menggunakan kasa steril setelah dilakukan perawatan. Hal ini mencegah luka dari kontaminasi bakteri dan udara kotor dan memeberikan rasa nyaman menta dan fisik pada hewan percobaan. Maka dari itu perawatan dan pengobatan antara perlakukan kelompok 1 dan peralukan kelompok 2 tidak dibeda-bedakan yakni mendapatkan perlakuan dan perawatan yang sama.

Perbandingan Efektifitas Ekstrak Etanol Daun Binahong (Anredera cordifolia (Ten) Steenis)dengan MEBO (Moist Exposed Burn Oinment)terhadap Penyembuhan Luka Bakar Derajat II A Pada Tikus Putih Jantan (Rattus Norvegicus)

Berdasarkan hasil perhitungan statistik Independent T-Test dengan menggunakan tingkat $\alpha<0,05$ didapatkan hasil $\rho(0,02)<\alpha$ $(0,05)$ yang artinya H1 diterima sehingga ada 
perbandingan efektifitas ekstrak etanol daun binahong (anredera cordifolia (ten) steenis) dengan mebo (moist exposed burn ointment) terhadap luka bakar derajat IIA pada tikus putih jantan (rattus norvegicus).

Pada hasil yang tersaji menunujukkan bahwa pada perlakuan kelompok 1 rata-rata waktu dalam proses penyembuhan luka mendapat hasil mean sebesar 13,73, sedangkan pada hasil yang tersaji menunujukkan bahwa pada perlakuan kelompok 2 rata-rata waktu dalam proses penyembuhan luka mendapat hasil mean sebesar 13,34.

Sesuai dengan teori Irma dan Anik 2013, kriteria dalam proses penyembuhan luka antara lain mulai dari ukuran luka, eksudat luka, kulit sekitar luka, tepi luka, dan infeksi pada luka. Hal ini sangat di perlukan untuk mengobservasi kondisi luka pada hewan percobaan.

Menurut peneliti, dalam melakukan penilaian kondisi luka harus melihat dengan jelas kondisi luka bakar derajat II A yang ada di punggung hewan percobaan tikus putih, karena pada penyembuhan luka ini dipengaruhi oleh hasil tersebut terutama pada perlakuan kelompok 1 menggunakan ekstrak etanol daun binahong waktu penyembuhannya sangat cepat dan efektif.

Pada penelitian yang meneliti tentang kandungan daun-daun tanaman, menjelaskan bahwa didalam daun binahong terdapat zat-zat seperti saponin, flanoid, minyak astiri, asam oleanolik, asam askorbat, terpenoid dan alkoid (Annisa, 2013). Diantara zat-zat tersebut terdapat beberapa zat yang dapat mempercepat proses penyembuhan luka secara efektif yaitu minyak astiri, asam oleanolik, dan alkaloid. Zat tersebut berperan sebagai antibakteri dan anti inflamasi. Pada penelitian yang dilakukan oleh Persada AN, dkk pada tahun 2012, peneltian ini bertujuan untuk mengetahui perbandingan tingkat kesembuhan luka bakar derajat II antara pemberian topical daun binahong tumbuk dan hidrogel pada tikus putih (Rattus Norvegicus). Enam ekor tikus masingmasing diberi tiga perlakuan. Perlakuan terdiri atas kelompok binahong (K1) dan hidrogel (K2). Setelah 14 hari, dilakukan pengukuran diameter luka dan sampel diambil untuk pemeriksaan mikroskopis. Secara mikroskopis didapatkan hasil rata-rata persentase kesembuhan K1: 4,5 dan K2 4,1. Kesimpulannya adalah tingkat kesembuhan luka bakar derajat II dengan pemberian binahong lebih tinggi dibandingkan hydrogel pada gambaran mikroskopis.

Menurut peneliti, dalam melakukan penelitian luka harus di perhatikan kesehatan hewan percobaan, kondisi luka, tanaman herbal yang akan dioleskan serta lingkungan. Dimana penyembuhan luka di pengarui oleh kandungan yang terdapat pada tanaman herbal yang digunakan sehingga mempercepat proses penyembuhan luka bakar derajat II A.

Dengan demikian,ekstrak daun binahong (anredera cordifolia (ten) steenis)sangat bermanfaat dalam mempercepat proses penyembuhan luka bakar derajat IIA pada tikus putih (Rattus norvegicus) jantan galur wistar, kandungan-kandungan dalam tanaman tersebut seperti flavonid, polifenol, dan asam olenolik sebagai anti infalamsi, antioksidan, antibakteri, dan antibiotik memiliki efek fisiologi dalam penyembuhan luka menjadi lebih cepat dan tidak terjadi infeksi dan kerusakan jaringan pada luka bakar derajat IIA.

Dapat disimpulkan dari hasil penelitian penyembuhan luka bakar derajat II A pada kelompok perlakuan 1 yaitu menggunakan ekstrak etanol daun binahong (anredera cordifolia (ten) steenis) ternyata dapat menyembuhkan luka bakar dengan cepat dan efektif, dalam waktu penyembuhan pada fase poliferasi yaitu selama 10 hari. Namun tidak kalah dengan salep MEBO (Moist Exposed Burn Oinment) pada kelompok perlakuan 2 yang perbandingan efektifitas penyembuhan pada luka bakar derajat II A hanya selisih 1 hari dari tingkat kesembuhan menggunakan ekstrak etanol daun binahong (anredera cordifolia (ten) steenis) yaitu selama 11 hari. Keduanyasama - sama memiliki kandungan yang dapat mempercepat proses penyembuhan luka bakar derajat II A secara efektif.

\section{SIMPULAN}

Ada perbandingan efektifitas ekstrak etanol daun binahong (anredera cordifolia (ten) steenis) dengan mebo (moist exposed burn ointment) terhadap luka bakar derajat II A pada tikus putih jantan (rattus norvegicus). Pemberian ekstrak etanol daun binahong (anredera cordifolia (ten) steenis) lebih efektif terhadap luka bakar derajat II A secara sig. yaitu rata-rata 10 hari bila dibandingkan dengan pemberian MEBO (moist exposed burn ointment) yang rata-rata sembuhnya 11 hari. 


\section{SARAN}

Agar Masyarakat mampu membedakan keefektifan tentang penggunaan alternatif obat yang berasal dari topikal herbal yang mempunyai fungsi sangat baik terhadap lama penyembuhan luka bakar derajat II secara cepat dan efektif

Diadakan penelitian lanjutan yang bersifat konfirmasi untuk mengetahui dengan jelas komponen-komponen yang terkandung didalam daun binahong (anrederacordifolia (ten) steenis) yang dapat mempercepat penyembuhan luka

Sebagai profesi harus terus mencari alternatif pengobatan dan perawatan pada proses penyembuhan luka bakar dengan cara melakukan penelitian dalam pemilihan dan pemberian alternatif obat secara baik dan benar sesuai dengan standar operasional yang ada.

\section{DAFTAR PUSTAKA}

Astuti et al., 2011. 'Efektifitas Salep Ekstrak Daun Binahong (Anrederacordifolia (Ten) Steenis) Terhadap Proses Penyembuhan Luka Bakar Derajat II Termal Pada Tikus Putih (Rattus Norvegicus)', Universitas Muhammadiyah Yogyakarta. Yogyakarta.

Dafit . 2012. 'Penanganan Luka Secara Tepat Sesuai Dengan Jenis Luka'. Indonesian Woun Healing Society, Journal of Advance Nursing, vol. 42 hh. 90-100.

De Launa \& Latner, 2011. 'Kombustion derajat II', Dinas Kesehatan Propinsi Akademi Gizi Surabaya, Journal of Advance Nursing, vol. 30 hh. 20-30.

Gauglitz, 2012. 'Sejarah Penggunaan Salep Moist Exposed Burn Oinment (MEBO) Terhadap Pasien Penderita Luka Bakar', Fakultas Kedokteran Universitas Muhammadiyah Malang. Malang.

Hindi, 2013. 'Sejarah Penggunaan Salep Moist Exposed Burn Oinment (MEBO) Terhadap Pasien Penderita Luka Bakar', Fakultas Kedokteran Universitas Muhammadiyah Malang. Malang.

Hardjito $\mathrm{K}$ et al., 2012. 'Identifikasi Fase Penyembuhan Luka Berbasis Citra', Jurusan Teknik Mesin Politeknik Negeri Lhoksumawe. Lhoksumawe, Banda Aceh-Medan.

Heriyanto, Bambang. 2013. Metode Penelitian Kuantitatif. Surabaya: PMN.
Irma, PuspitaArisanty. 2013. Manajamen Perawatan Luka. Jakarta: EGC.

Isrofah, 2013. 'Efektifitas Salep Ekstrak Daun Binahong (Anrederacordifolia (Ten) Steenis) Terhadap Proses Penyembuhan Luka Bakar Derajat II Termal Pada Tikus Putih (RattusNorvegicus)'. Universitas Pekalongan. Universitas Muhammadiyah Yogyakarta.

Jeschkeet al.,2011.'Potensi\& Status Global Terhadap Penanganan Strategi Untuk Neonicotinoid', Jurnal of Agricultural, vol. 15 hh. 41-45.

Jewo $d k k$., 2009. 'Sejarah Penggunaan Salep Moist Exposed Burn Oinment (MEBO) Terhadap Pasien Penderita Luka Bakar', Fakultas Kedokteran Universitas Muhammadiyah Malang. Malang.

Juanda, 2012. 'Ilmu Penyakit Kulit dan Kelamin', Jakarta :Fakultas Kedoteran Universitas Indonesia Jakarta. Vol 5, no 5.

Kartini\& Rio, 2011. 'Penggunaan kream Silver Sulfadiazine Terhadap Penyembuhan Luka Bakar Pada Tikus Putih (RattusNorvegicus)' Jurnal of Advance Nursingvol. 5 hh. 35-40.

Kunavi, 2010. 'Uji Aktivitas Anti Bakteri Ekstrak Daun Binahong Terhadap Bakteri Stapylococcus Aureusdan Peseudomonas Aerugenosa'. Universitas Islam Negeri Maulana Maliq Ibrahim Malang.

Majit \& Sarwo, 2013, 'Buku Pintar Perawatan Pasien Luka Bakar'. Departemen Kesehatan. Jakarta. Vol 3 no 27.

Manoi, 2012. 'Pengaruh Pemberian Ekstrak Daun Binahong (Anredera cordifolia (Ten) Steenis) Terhadap Kesembuhan Luka Infeksi Staphylococcus Aureus Pada Mencit'. Jurusan Analis Kesehatan Poltekkes Kemenkes Surabaya.

Martina \& Wardhana 2013. 'Perbandingan Tingkat Kesembuhan Luka Bakar Derajat II Antara Pemberian Madu Topikal Nektar Kopi dengan Silver Sulfadiazine pada Tikus Putih (RattusNorvegicus) Jantan Galur Spraguedaule'. Fakultas Kedokteran Universitas Lampung.

Munajat, Yefta 20012. 'Luka Bakar Pengetahuan Klinis Praktis', Fakultas Kedokteran Universitas Indonesia. Journal of Advance Nursing, vol. 20 hh.10-15. 
Notoatmodjo, 2011. 'Buku Metodologi Penelitian Kesehatan'. Edisi Revisi Cetakan Pertama. Anggota IKAPI No. 112-DKI-90. Jakarta.Vol 5 no 25.

Nursalam, 2013. 'Buku Konsep Dan Penerapan Metodologi Penelitian Ilmu Keperwatan'. Edisi 2. Penerbit Salemba Medika. Jakarta.

Pajuet al., dalam Makalunsenge, 2009. 'Uji Aktifitas Antibakteri Ekstrak Daun Binahong Terhadap Bakteri Staphylococcus Aureus'. Jurusan Kimia FMIPA Universitas Negeri Gorontalo. Gorontalo-Sulawesi.

Perry \& Potter, 2010. 'Buku Ajar Fundamental Keperawatan Pada Proses dan Praktik'. Fakultas Keperawatan Universitas Diponegoro. Semarang.Edisi 4 Voll.

Rahmawati dkk dalam Salimi, 2014. 'Kajian Senyawa Anti Oksidan dan Anti Inflamasi Tumbuhan Obat Binahong (Anrederacordifolia (Ten) Steenis)'. Universitas Negeri Gorontalo. Sulawesi. Journal of Advance Nursing.

Setyarini EA et all., 2013, 'Identifikasi Fase Penyembuhan Luka Berbasis Citra'. Jurusan Teknik Mesin Politeknik Negeri Lhoksumawe. Lhoksumawe, Banda Aceh-Medan.

Sjamsuhidajat \& Jong, 2004, 'Perbandingan Tingkat Kesembuhan Luka Bakar Derajat II Antara Pemberian Madu Topikal Nektar Kopi dengan Silver Sulfadiazine pada Tikus Putih (Rattus Norvegicus) Jantan Galur Spraguedaule', Journal of Advance Nursing, vol. 20hh. 200-230.

Stylianou et al., 2014. 'Tingkat Keparahan Cedera Terhadap Usia Pasien Dan Adanya Kelainan Penyerta'.Fakultas Kedokteran Universitas Sumatra Utara. Medan

Sugiyono, 2012. 'Buku Statistik Non Parametri suntuk Penelitian'. Anggota Ikatan Penerbit Indonesia (IKAPI). Jakarta.

Sulistyani dkk, 2012. 'Uji Aktivitas Anti Bakteri Ekstrak Etil Asetat Daun Binahong (Anrederacordifolia (Ten) Steenis) terhadap Shigella flexneri Beserta Profil Kromatografi Lapis Tipis'.Fakultas Farmasi Universitas Ahmad Dahlan Yogyakarta.

Suseno dalam Wardani, 2015. 'Pengaruh Pemberian Daun Binahong Terhadap Kualitas Luka Perium Pada Ibu Nifas Di
Rumah Sakit Sarifah Ambarni Rato Eboh Bangkalan Madura'.Journal of Advance Nursing. 